\title{
TSH-Suppressive Therapy: A Thorny Issue
}

\author{
Itala Marina Baldini ${ }^{1},{\underline{\text { Cristina } \text { Cocino }^{1}}}$, Sonia Seghezzi ${ }^{2}$, Maria Domenica Cappellini $^{1}$ \\ ${ }^{1}$ UOC Medicina Interna, Fondazione IRCCS Ca' Granda Ospedale Maggiore Policlinico, Milano, Italy \\ ${ }^{2} \mathrm{ICH}$ Humanitas, EAS Pronto Soccorso, Rozzano (MI), Italy
}

Received: 02/12/2016

Accepted: 05/12/2016

Published: 22/12/2016

How to cite this article: Baldini IM, Cocino C, Seghezzi S, Cappellini MD. TSH-suppressive therapy: a thorny issue. EJCRIM 2016;3: doi:10.12890/2016_000547.

Conflicts of Interests: The Authors declare that there are no competing interests.

This article is licensed under a Commons Attribution Non-Commercial 4.0 License

\section{ABSTRACT}

Thyroid stimulating hormone (TSH)-suppressive therapy with levothyroxine is a cornerstone of thyroid carcinoma follow-up therapy, but the achievement of therapeutic goals must be balanced against L-T4 side effects. We describe the case of a 64-year-old cardiopathic patient with papillary thyroid carcinoma and autoimmune thyroiditis, whose cardiac condition worsened during TSH-suppressive therapy. TSH concentrations also fluctuated widely because of changing intestinal absorption due to coeliac disease.

\section{LEARNING POINTS}

- TSH-suppressive therapy with levothyroxine (L-T4) to prevent thyroid carcinoma relapse can be a tricky problem in the presence of comorbidities.

- The recent American Thyroid Association guidelines are a useful reference for complex cases of thyroid carcinoma.

- When strict TSH control is crucial, the L-T4 liquid solution may be a valuable tool.

\section{KEYWORDS}

Thyroid carcinoma; TSH-suppressive therapy; intestinal malabsorption

\section{CASE PRESENTATION}

A 64-year-old woman with coeliac disease and autoimmune thyroiditis was examined 2 years after thyroidectomy with lymphadenectomy for carcinoma (January 2006). The histopathological report described multifocal papillary carcinoma, follicular variant, associated with lymphocytic thyroiditis; the main nodule $(6 \mathrm{~mm})$ had infiltrated the thyroid capsule without affecting the fat tissue, vascular or lymphatic vessels (TNM pT1 (G2) pNO M0). Ten months after surgery, radioiodine remnant ablation had been performed. Subsequent whole body scintigraphy and periodic ultrasound scans were not suggestive of relapse; thyroglobulin concentrations were undetectable but antithyroglobulin antibody positivity persisted.

The patient also had ischaemic heart disease, diagnosed on the basis of myocardial scintigraphy as she refused coronarography. At first examination at our clinic (March 2008), thyroid stimulating hormone (TSH) was suppressed on levothyroxine (L-T4) $3 \mu \mathrm{gg} / \mathrm{kg} / \mathrm{day}$, but the treatment was not tolerated due to frequent angina and premature ventricular beats despite beta-blocking therapy. Consequently, L-T4 was tapered to the dose allowing satisfactory control of the side effects ( $2.4 \mu \mathrm{g} / \mathrm{kg} / \mathrm{day})$. The results of periodic tests are shown in Table 1. In March 2009, the patient's cardiac condition deteriorated and atrial fibrillation was noted; a CT scan revealed coronary artery disease that required angioplasty. At the same time, the periodic neck ultrasound showed a single $12 \times 7 \mathrm{~mm}$ lymph node suspect for local relapse. As a result, TSH inhibition became more pressing even in the absence of significant changes in blood tests or pathological uptake areas at 
repeated whole body scintigraphy. However, we delayed any L-T4 increase in view of the patient's unstable cardiac condition. Over the following observation period, the L-T4 dosage was frequently modified in response to wide TSH fluctuations, until January 2015 when $\mathrm{TSH}=12.7 \mathrm{mIU} / \mathrm{I}$ was registered. Although the patient declared good compliance with a gluten-free diet except on rare occasions, we suspected problems with absorption and switched from L-T4 tablets to the liquid formulation at the unchanged dose of $2.1 \mu \mathrm{g} / \mathrm{kg} / \mathrm{day}$, and recorded optimal TSH suppression after 6 weeks. Thereafter, follow-up was negative for relapse.

\begin{tabular}{|c|c|c|c|c|c|}
\hline Date & Weight, kg & L-T4 dose & $\begin{array}{c}\text { TSH, } \\
\mathrm{mIU} / \mathrm{I}(\mathrm{nv} 0.28-4.3)\end{array}$ & $\begin{array}{l}\mathrm{Tg}, \\
\mu \mathrm{g} / \mathrm{I}\end{array}$ & $\begin{array}{c}\text { Anti-Tg antibodies, } \\
\text { IU } / \mathrm{ml}(\mathrm{nv}<60)\end{array}$ \\
\hline & & Tablet & & & \\
\hline 05/03/2008 & 75 & $\begin{array}{l}225 \mu \mathrm{g} / \text { day } \\
3 \mu \mathrm{g} / \mathrm{kg} / \text { day }\end{array}$ & 0.04 & $<0.2$ & - \\
\hline $18 / 12 / 2008$ & 76 & $\begin{array}{c}193 \mu \mathrm{g} / \mathrm{day} \\
2.5 \mu \mathrm{g} / \mathrm{kg} / \text { day }\end{array}$ & $0.01-0.02$ & $<0.2$ & $166-357$ \\
\hline $28 / 05 / 2009$ & 77 & $\begin{array}{c}190 \mu \mathrm{g} / \text { day } \\
2.4 \mu \mathrm{g} / \mathrm{kg} / \text { day }\end{array}$ & $0.02-0.34$ & $<0.2$ & $174-219$ \\
\hline 23/09/2011 & 80 & $\begin{array}{c}185 \mu \mathrm{g} / \text { day } \\
2.3 \mu \mathrm{g} / \mathrm{kg} / \text { day }\end{array}$ & $0.3-2.3$ & $<0.2$ & $110-190$ \\
\hline $21 / 03 / 2014$ & 81 & $\begin{array}{c}170 \mu \mathrm{\mu g} / \mathrm{day} \\
2.1 \mu \mathrm{g} / \mathrm{kg} / \mathrm{day}\end{array}$ & $0.17-5.7$ & $<0.2$ & $<60$ \\
\hline \multirow[t]{2}{*}{$23 / 01 / 2015$} & 84 & $\begin{array}{l}165 \mu \mathrm{g} / \mathrm{day} \\
2 \mu \mathrm{g} / \mathrm{kg} / \mathrm{day}\end{array}$ & $4.5-12.4$ & $<0.2$ & $<60$ \\
\hline & & Liquid solution & & & \\
\hline 03/07/2015 & 84 & $\begin{array}{c}175 \mu \mathrm{g} / \text { day } \\
2.1 \mu \mathrm{kg} / \mathrm{day}\end{array}$ & 0.05 & $<0.2$ & $<60$ \\
\hline
\end{tabular}

Table 1. Biochemical tests and L-T4 doses

Tg, thyroglobulin; TSH, thyroid stimulating hormone

\section{DISCUSSION}

The challenge we describe is not unusual for endocrinologists trying to minimize cancer recurrence risk while also limiting TSH-suppression side effects.

Our patient had been classified as belonging to the high-risk category based on American Thyroid Association (ATA) guidelines ${ }^{[1]}$. Supraphysiological doses of L-T4 were therefore prescribed as it was mandatory to maintain TSH levels below $0.1 \mathrm{mU} /$ [1,2] $^{[0}$ decrease the risk of recurrence ${ }^{[1-5]}$. However, the potential benefits of reaching the therapeutic goal must always be balanced against possible harm from subclinical thyrotoxicosis ${ }^{[1,2]}$, a complex undertaking in this case due to the coexistence of cardiac ischaemic and arrhythmogenic disease. The recent ATA guidelines are particularly useful in situations like these, as they give strict indications for the thyrotropin targets, taking both L-T4 side effects and co-morbidities into consideration. According to these guidelines, the recommended TSH target is between 0.5 and $2 \mathrm{mU} / \mathrm{l}$ in the presence of specific conditions: an indeterminate response (anti-TG antibodies stable or declining without structural or functional disease), menopause, age $>60$, and in particular atrial fibrillation ${ }^{[6]}$.

Our patient had coeliac disease, which may mean L-T4 doses need to be increased to reach the target TSH ${ }^{[7-11]}$. In a retrospective study, Collins et al. demonstrated that the mean initial daily dose of L-T4 needed to reach euthyroidism was higher in patients with untreated coeliac disease and hypothyroidism than in those with hypothyroidism alone ${ }^{[12]}$.

In our patient, switching from tablets to the liquid formulation overcame the negative effect of coeliac disease on drug absorption, producing more stable TSH concentrations with lower L-T4 doses; this effect is connected with the intrinsic characteristics of the drug. Levothyroxine is a lipophilic molecule that is absorbed in the upper intestinal tract. The tablet formulation contains a stable salt and excipients, which must be dissolved at the gastric acid $\mathrm{pH}$ to convert sodium L-T4 into a lipophilic molecule ${ }^{[13]}$; this will reach the duodenum and jejunum, where around $70 \%$ of the tablet L-T4 content will be absorbed ${ }^{[14-16]}$. The liquid formulation contains only L-T4 dissolved in a lipophilic solution of glycerine and ethanol; L-T4 also maintains its stability when added to breakfast beverages ${ }^{[17,20]}$.

In an in vivo study comparing the three available formulations of L-T4 (tablet, soft gel capsule, liquid solution), the liquid solution showed the best pharmacokinetics indices and the fastest blood peaks ${ }^{[18,19,21]}$. Brancato et al. reported a significant decrease in serum TSH levels in $68 \%$ of patients switched from tablets (taken according recommendations) to the liquid solution at the same dose. Interestingly, the patients in whom serum TSH decreased had a greater prevalence of factors known to interfere with L-T4 intestinal absorption (gastrointestinal diseases or drugs) ${ }^{[22]}$. 


\section{CONCLUSION}

Achieving a balance between therapeutic goals and the side effects of L-T4 is a thorny issue, especially when comorbidities are present. The oral solution is a valuable tool in complex cases where strict control of therapeutic goals is crucial.

\section{REFERENCES}

1. Cooper DS, Doherty GM, Haugen BR, Kloos RT, Lee SL, Mandel SJ, et al. The American Thyroid Association Guidelines Taskforce. Management guidelines for patients with thyroid nodules and differentiated thyroid cancer. Thyroid 2006;16:121-125.

2. Cooper DS, Doherty GM, Haugen BR, Kloos RT, Lee SL, Mandel SJ, et al. The American Thyroid Association (ATA) Guidelines Taskforce on Thyroid Nodules and Differentiated Thyroid Cancer. Revised American Thyroid Association management guidelines for patients with thyroid nodules and differentiated thyroid cancer. Thyroid 2009;19:11801187.

3. Biondi B, Wartofsky L. Treatment with thyroid hormone. Endocr Rev 2014;35:433-512.

4. Pacini F, Castagna MG. Approach to and treatment of differentiated thyroid carcinoma. Med Clin North Am 2012;96:369-383.

5. Garber JR, Cobin RH, Gharib H, et al. American Association of Clinical Endocrinologists and American Thyroid Association Task Force on Hypothyroidism in Adults. Clinical practice guidelines for hypothyroidism in adults: co-sponsored by the American Association of Clinical Endocrinologists and the American Thyroid Association. Endocr Pract 2012;18:988-1028.

6. Haugen BR, Alexander EK, Bible KC, Doherty GM, Mandel SJ, Nikiforov YE, et al. The American Thyroid Association Guidelines Task Force on Thyroid Nodules and Differentiated Thyroid Cancer. 2015 American Thyroid Association management guidelines for adult patients with thyroid nodules and differentiated thyroid cancer. Thyroid 2016;26:48,72-73.

7. Jiskra J, Limanova Z, Vanickova Z, Kocna P. IgA and IgG antigliadin, IgA anti-tissue transglutaminase and antiendomysial antibodies in patients with autoimmune thyroid diseases and their relationship to thyroidal replacement therapy. Physiol Res 2003;52:79-88.

8. d'Esteve-Bonetti L, Bennet AP, Malet D, et al. Gluten-induced enteropathy (coeliac disease) revealed by resistance to treatment with levothyroxine and alfacalcidol in a sixtyeight-year old patient: a case report. Thyroid 2002;12:633-636.

9. McDermott JH, Coss A, Walsh CH. Celiac disease presenting as resistant hypothyroidism. Thyroid 2005;15:386-388.

10. Chamberland D, Weight C, Rasmussen M, et al. Thyroxine malabsorption in a patient with type 1 diabetes and celiac disease. Endocr Pract 2005;11:203-204.

11. Caputo M, Brizzolara R, Schiavo M, et al. Occurrence of overt celiac disease in the elderly following total thyroidectomy. J Endocrinol Invest 2006;29:831-833.

12. Collins D, Wilcox R, Nathan M, Zubarik R. Celiac disease and hypothyroidism. Am J Med 2012;125:278-282.

13. Centanni M, Gargano L, Canettieri G, et al. Thyroxine in goiter, Helicobacter pylori infection, and chronic gastritis. N Engl J Med 2006;354:1787-1795.

14. Hays MT, Nielsen RK. Human thyroxine absorption: age effects and methodological analyses. Thyroid 1994;4:55-64.

15. Benvenga S, Bartolone L, Squadrito S, et al. Delayed intestinal absorption of levothyroxine. Thyroid 1995;5:249-253.

16. Hays MT. Localization of human thyroxine absorption. Thyroid 1991;1:241-248.

17. Vita R, Saraceno G, Trimarchi F, Benvenga S. A novel formulation of L-thyroxine (L-T4) reduces the problem of L-T4 malabsorption by coffee observed with traditional tablet formulations. Endocrine 2013;43:154-160.

18. Colucci P, D'Angelo P, Mautone G, et al. Pharmacokinetic equivalence of a levothyroxine sodium soft capsule manufactured using the new Food and Drug Administration potency guidelines in healthy volunteers under fasting conditions. Ther Drug Monit 2011;33:355-361.

19. Santaguida M, Virili C, Gatto I, et al. A novel therapeutic approach for patients with gastric disorders and T4 malabsorption: thyroxine softgel preparation. Thyroid 2013;23(S1):A53.

20. Bernareggi A, Grata E, Pinorini MT, et al. Oral liquid formulation of levothyroxine is stable in breakfast and may improve thyroid patient compliance. Pharmaceutics 2013;5:621633.

21. Yue CS, Scarsi C, Ducharme MP. Pharmacokinetics and potential advantages of a new oral solution of levothyroxine vs. other available dosage forms. Arzneimittelforschung 2012;62:631-636

22. Brancato D, Scorsone A, Saura G, et al. Comparison of TSH levels with liquid formulation versus tablet formulations of levothyroxine in the treatment of adult hypothyroidism. Endocr Pract 2014;20:657-662. 